Eur J Clin Chem Clin Biochem

1995: 33:927-932

(C) 1995 Walter de Gruyter \& Co. Berlin $\cdot$ New York

\title{
Cortisol in Saliva - Reference Ranges and Relation to Cortisol in Serum
}

\author{
By Elisabeth Aardal and Ann-Charlotte Holm \\ Department of Clinical Chemistry, Faculty of Health Sciences, Linköping, Sweden
}

(Received May 20/August 28, 1995)

\begin{abstract}
Summary: The aim of this study was to establish morning and evening reference ranges for cortisol in saliva. Another objective was to compare the concentrations of the mainly free cortisol in saliva to those of total cortisol in serum as determined with a commercial radioimmunoassay. The concentrations were determined in matched samples of saliva and serum collected at $8 \mathrm{am}$ and $10 \mathrm{pm}$ from 197 healthy volunteers. The saliva samples were stable for at least 7 days at room temperature and for 9 months at $-20^{\circ} \mathrm{C}$. Reference ranges, the central $95 \%$, were estimated to $3.5-27.0 \mathrm{nmol} / 1$ at $8 \mathrm{am}$ and $<6.0 \mathrm{nmol} / 1$ at $10 \mathrm{pm}$. The intra-assay coefficient of variation (CV) was below $5 \%$ and total $\mathrm{CV}$ below $10 \%$. The relation between the cortisol concentrations in serum and saliva was nonlinear with $\mathrm{r}=0.86$ for serum concentrations $<450 \mathrm{nmol} / \mathrm{l}$ and $\mathrm{r}=0.44$ for serum concentrations $\geq 450 \mathrm{nmol} / 1$. In conclusion, the satisfactory precision of the analysis and the simple non-invasive sampling procedure suggest that saliva may be used for cortisol measurements in situations where blood sampling is difficult to perform.
\end{abstract}

\section{Introduction}

Determination of cortisol in serum and urine has long been used in the assessment of adrenocortical function and other disturbances in the hypothalamic-pituitaryadrenocortical axis. It also serves in the diagnosis of depressive disorders $(1,2)$, and as the most frequently used marker for different kinds of stress-induced reactions $(3-6)$. In serum, cortisol is mainly protein-bound and is usually measured as such. The analysis of free cortisol in serum is time-consuming and expensive and not suitable for clinical routine (7). In urine cortisol exists only in free form. Renal secretion, however, is dependent on glomerular and tubular function and the measured daily secretion rate depends on a correct 24hour collection of urine. Hence the urinary cortisol does not always correctly reflect the free cortisol concentration in serum.

In serum, cortisol is to $90-95 \%$ bound to proteins, about $60 \%$ to transcortin and $30 \%$ to albumin. Transcortin binds cortisol with high affinity but low capacity, whereas albumin has a low affinity but an almost infinite capacity for cortisol. Transcortin is saturated at a serum cortisol concentration of $450-500 \mathrm{nmol} / 1(7,8)$, thus already within the reference range at 8 am of 200-800 nmol/l. At levels exceeding transcortin saturation, the unbound fraction increases. In various clinical conditions the transcortin concentration and thereby the total serum cortisol concentration changes. Pregnancy and the use of oral contraceptives and oestrogens increase the transcortin concentration 2-3 times. Whether the free, biologically active fraction changes or not is at present a controversial issue $(9,10)$. In certain liver and kidney diseases and in various catabolic conditions the level of transcortin decreases, resulting in decreased serum cortisol concentrations, while the unbound fraction is said to remain constant (9).

In saliva, cortisol appears mainly in free form. Its concentration is approximately two thirds of unbound cortisol in serum and correlates well with this serum fraction (9). About $15 \%$ of salivary cortisol is bound to transcortin, a normal component of uncontaminated parotid saliva $(11-13)$. The transfer from serum to saliva occurs by free diffusion of unbound cortisol through the acinar cells of the salivary glands $(14,15)$ and the equilibrium between serum and saliva is reached in less than $5 \mathrm{~min}$ - 
utes (9). The salivary cortisol concentration is independent of saliva flow rate and of the serous and mucous content (16-18).

The above described disadvantages when measuring free cortisol in serum and urine are circumvented with the use of saliva. The aim of this study was therefore to evaluate our current cortisol method, used for serum and urine, for measurement of the cortisol concentrations in saliva and to establish its reference ranges. Also, by a simultaneous sampling of blood a correlation could be made with the cortisol concentration in serum.

\section{Materials and Methods}

\section{Subjects}

The study material comprised samples from 197 healthy individuals, 123 men (age range 20-70 years) and 74 women (age range 20-70 years). The material consisted of 66 men from the local rescue service and 57 men and 74 women randomly selected from the local population. The subjects were not taking any kind of steroid compound; except contraceptives (13 women). All subjects contributed at least one morning and one evening saliva sample during a 24-hour period, altogether 434 samples. Blood was also drawn, the venipuncture being performed after the saliva collection in order to avoid stress-induced increase in cortisol concentration. In ten of the subjects ( 4 men, 6 women), the intra-individual variation was determined on morning and evening samples collected within 24 hours on three occasions at one week's interval. In order to exclude possible variations related to leisure time, the samples were collected on Tuesdays, Wednesdays or Thursdays. The morning samples were collected at $8 \mathrm{am} \pm 45$ minutes and the evening samples at $10 \mathrm{pm} \pm 45$ minutes.

\section{Procedure of saliva collection}

To avoid an increase in cortisol concentration and contamination of the oral cavity due to food intake or smoking (19), the test subjects were instructed not to eat, drink or smoke later than 60 minutes before the samples were collected. The subjects were not allowed to expose themselves to physical strain later than $60 \mathrm{~min}$ utes before sampling and they were instructed to rest lying down during the last 30 minutes. Brushing of the teeth was not allowed during the 60 minutes preceding saliva collection to minimize the risk of blood contamination. The mouth was to be rinsed with water 15 minutes prior to saliva collection.

The saliva was collected in a Salivette ${ }^{\circledR}$ test tube (Sarstedt, Rommelsdorf, Nümbrecht, Germany) equipped with an insert containing a steril cotton-wool swab through which the saliva passes during centrifugation, yielding a saliva free from particles. The swab was drained with saliva during 60 seconds, as recommended by the manufacturer, and was then put back into the insert. Within this time, a few subjects did not produce enough saliva, i. e. $0.5 \mathrm{ml}$. Swabs treated with citric acid were tested for morning and evening samples from 5 individuals for comparison with plain swabs. None of the test subjects complained of any discomfort in connection with the saliva collection except for the bad taste of the citric acid treated swabs.

\section{Preparation of samples}

The samples were centrifuged at $1900 \mathrm{~g}$ for 15 minutes at room temperature and were then frozen at $-20^{\circ} \mathrm{C}$ within 4 hours after sample collection. The longest storage time was 9 months. Prior to analysis samples were thawed at room temperature and tested for blood contamination using a HemoCue ${ }^{\circledR}$ (HemoCue AB, Ängelholm, Sweden) microcuvette for hacmoglobin determination. All samples from one individual were analysed in the same assay.

\section{Method}

Cortisol was measured by a solid phase radioimmunoassay, CoatA-Count from Diagnostic Products Corpbration (DPC), Los Angeles, USA. This kit is used in our laboratory for the analysis of cortisol in serum and urine. For serum our current reference range is $200-800 \mathrm{nmol} / 1$ at $8 \mathrm{am}$ and $<300 \mathrm{nmol} / 1$ at $10 \mathrm{pm}$. For detection of the low concentrations present in saliva, the sensitivity of the method needed to be increased. Following the instructions of the manufacturer the sample volume was therefore increased from $25 \mu \mathrm{l}$ to $200 \mu \mathrm{l}$ and the incubation time extended from 45 minutes at $37^{\circ} \mathrm{C}$ to 3 hours at room temperature. Calibrators and controls (DPC) were also adapted to saliva analysis by dilution in water $1: 10$. The measurable range was $0.5-138 \mathrm{nmol} / \mathrm{l}$. Quality controls of three different concentrations $(2.3,12.6$ and $123 \mathrm{nmol} / \mathrm{l})$ were processed at the beginning and at the end of each assay. In assays of more than 50 samples, controls were also processed in the middle of the assay.

\section{Statistics}

Statistical analyses were made using Mann-Whitney's non-parametric test for unpaired measurements (20).

\section{Results}

The detection limit of the method was assessed by analysing the zero calibrator in duplicate in eighteen different assays. Defined as apparent concentration 2 standard deviations below mean counts per minute for the zero calibrator, the detection limit was $0.5 \mathrm{nmol} / \mathrm{l}$.

The precision was examined by analysing controls, one sample with high and one sample with low cortisol concentration in duplicate in eight different assays. These samples were frozen in aliquots to avoid refreezing. The coefficients of variation (CV) were calculated from the means of the duplicates. The intra-assay CV was $4.3 \%$ for values $0.5-10.0 \mathrm{nmol} / 1$ and $3.6 \%$ for values $10.1-$ $123 \mathrm{nmol} / \mathrm{l}$. Total CV, intra- and inter-assay CV, was $8.3 \%$ for values $0.5-10.0 \mathrm{nmol} / \mathrm{l}$ and $5.1 \%$ for values $10.1-123 \mathrm{nmol} / \mathrm{l}$. On five occasions these samples were analysed at the beginning and at the end of an assay of more than 300 tubes without showing any drift of the measured cortisol concentration. For the serum samples in this study the total $\mathrm{CV}$, determined from ten means of duplicates of controls, was $7.9 \%$ and $4.4 \%$ for concentrations of 310 and $850 \mathrm{nmol} / \mathrm{l}$, respectively.

The accuracy of the method was assessed by recovery experiments where samples from four subjects were spiked with calibrators of three different concentrations. There was a good agreement between expected and observed results (tab. 1). The stability of the saliva samples was tested by analysing 3 samples with different cortisol concentrations stored under different conditions (tab. 2). The samples were stable at room:temperature for at least 
7 days and were also unaffected by freezing at $-20^{\circ} \mathrm{C}$ for up to 9 months. After refreezing, however, the cortisol concentrations showed a marked decrease. Use of citric acid treated swabs resulted in $10-70 \%$ higher concentrations.

Reference ranges for salivary cortisol were established from 195 morning and 195 evening samples (tab. 3).

Tab. 1 Recovery experiments. Samples from four different subjects spiked in dilution $1: 2$ with calibrators of different concentrations.

\begin{tabular}{|c|c|c|c|c|}
\hline \multirow[t]{2}{*}{ Sample } & \multicolumn{3}{|c|}{ Cortisol (nmol/l) } & \multirow{2}{*}{ Observed } \\
\hline & Calibrator & Expected & Observed & \\
\hline 5.0 & 138.0 & 71.5 & 71.4 & 1.00 \\
\hline 7.4 & 2.8 & 5.2 & 5.8 & 1.11 \\
\hline 7.4 & 27.8 & 17.6 & 18.4 & 1.04 \\
\hline 16.0 & 138.0 & 77.0 & 74.6 & 0.97 \\
\hline 21.0 & 138.0 & 79.5 & 74.0 & 0.94 \\
\hline
\end{tabular}

Women under the age of 40 had significantly higher cortisol concentrations than women over 40 . The 12 women, 21-40 years old, who were taking oral contraceptives (the 13th woman was over 40 years) had a mean concentration of $23 \mathrm{nmol} / \mathrm{l}$ at $8 \mathrm{am}$ and of 2.2 $\mathrm{nmol} / 1$ at $10 \mathrm{pm}$. The 42 untreated women in the same age groups had a mean concentration of $11.5 \mathrm{nmol} / \mathrm{l}$ at $8 \mathrm{am}$ and of $1.1 \mathrm{nmol} / 1$ at $10 \mathrm{pm}$. Beyond the age of 40 the cortisol concentrations appeared to decrease with increasing age, but the differences were without statistical significance. The reference ranges, defined as the central $95 \%$, were estimated to $3.5-27.0 \mathrm{nmol} / 1$ at $8 \mathrm{am}$ and $<6.0 \mathrm{nmol} / 1$ at $10 \mathrm{pm}$ for both sexes including all ages, and for practical reasons also the women on contraceptives. In $23(11 \%)$ of the evening samples the cortisol concentration was below the detection limit of the method.

The correlation between the cortisol concentrations in serum and saliva is presented in figure 1 . The relation-

Tab. 2 Stability of three saliva samples stored under different conditions.

\begin{tabular}{|c|c|c|c|c|}
\hline \multirow[t]{2}{*}{ Storage } & \multirow{2}{*}{$\begin{array}{l}\text { Time } \\
\text { (days) }\end{array}$} & \multicolumn{3}{|c|}{ Salivary cortisol (nmol/l) } \\
\hline & & Sample 1 & Sample 2 & Sample 3 \\
\hline Analyșed immediately & - & 2.7 & 7.1 & 18.9 \\
\hline Room temperature & 7 & 2.8 & 6.9 & 19.0 \\
\hline Refrigerator $\left(2-8^{\circ} \mathrm{C}\right)$ & 7 & 2.7 & 7.1 & 18.7 \\
\hline Freezer $\left(-20^{\circ} \mathrm{C}\right)$ & 30 & 2.7 & 7.0 & 18.9 \\
\hline Freezer $\left(-20^{\circ} \mathrm{C}\right)$ & 270 & 2.6 & 7.2 & 19.6 \\
\hline Refrozen $\left(-20^{\circ} \mathrm{C}\right)$ after thawing & $7+23$ & 2.3 & 6.6 & 18.3 \\
\hline
\end{tabular}

Tab. 3 Salivary cortisol concentrations (nmol/1) of the reference population.

\begin{tabular}{|c|c|c|c|c|c|c|}
\hline \multirow{3}{*}{$\begin{array}{l}\text { Age } \\
\text { (years) }\end{array}$} & \multirow[t]{3}{*}{ Sex } & \multirow[t]{3}{*}{$\mathrm{N}$} & \multicolumn{4}{|c|}{ Cortisol (nmol/l) } \\
\hline & & & \multicolumn{2}{|c|}{ Morning } & \multicolumn{2}{|c|}{ Evening } \\
\hline & & & Mean & Range & Mean & Range \\
\hline $21-30$ & $\begin{array}{l}5 \\
0\end{array}$ & $\begin{array}{l}26 \\
20\end{array}$ & $\begin{array}{l}10.0 \\
14.6^{*}\end{array}$ & $\begin{array}{l}3.1-20.5 \\
7.5-37.2\end{array}$ & $\begin{array}{l}2.2 \\
1.1\end{array}$ & $\begin{array}{l}<0.5-8.5 \\
<0.5-2.9\end{array}$ \\
\hline $31-40$ & $\begin{array}{l}\hat{0} \\
+\end{array}$ & $\begin{array}{l}37 \\
22\end{array}$ & $\begin{array}{l}12.1 \\
15.0 *\end{array}$ & $\begin{array}{l}3.3-42.8 \\
2.6-41.8\end{array}$ & $\begin{array}{l}1.4 \\
1.7\end{array}$ & $\begin{array}{l}<0.5-9.9 \\
<0.5-3.7\end{array}$ \\
\hline $41-50$ & $\begin{array}{l}\hat{0} \\
\stackrel{+}{q}\end{array}$ & $\begin{array}{r}30 \\
9\end{array}$ & $\begin{array}{l}11.4 \\
11.4\end{array}$ & $\begin{array}{l}4.9-30.0 \\
3.0-35.7\end{array}$ & $\begin{array}{l}1.6 \\
2.2\end{array}$ & $\begin{array}{r}<0.5-9.1 \\
0.7-5.0\end{array}$ \\
\hline $51-60$ & $\begin{array}{l}\hat{\delta} \\
\dot{q}\end{array}$ & $\begin{array}{l}21 \\
13\end{array}$ & $\begin{array}{l}10.3 \\
10.0\end{array}$ & $\begin{array}{l}3.1-22.4 \\
4.1-20.4\end{array}$ & $\begin{array}{l}1.6 \\
2.6\end{array}$ & $\begin{array}{r}<0.5-6.3 \\
0.6-7.0\end{array}$ \\
\hline $61-70$ & $\begin{array}{l}\text { a } \\
q\end{array}$ & $\begin{array}{r}7 \\
10\end{array}$ & $\begin{array}{l}9.7 \\
9.1\end{array}$ & $\begin{array}{l}4.7-18.2 \\
7.3-15.7 \\
\end{array}$ & $\begin{array}{l}2.1 \\
1.5\end{array}$ & $\begin{array}{l}0.7-3.7 \\
0.6-3.1\end{array}$ \\
\hline Total & 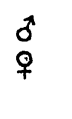 & $\begin{array}{r}121 \\
74 \\
195\end{array}$ & $\begin{array}{l}10.7 \\
12.0 \\
11.9\end{array}$ & $\begin{array}{l}3.1-42.8 \\
2.6-41.8 \\
2.6-42.8\end{array}$ & $\begin{array}{l}1.8 \\
1.8 \\
1.8\end{array}$ & $\begin{array}{l}<0.5-9.9 \\
<0.5-7.0 \\
<0.5-9.9\end{array}$ \\
\hline
\end{tabular}

$* p<0.005$ vs women over 40 years. 


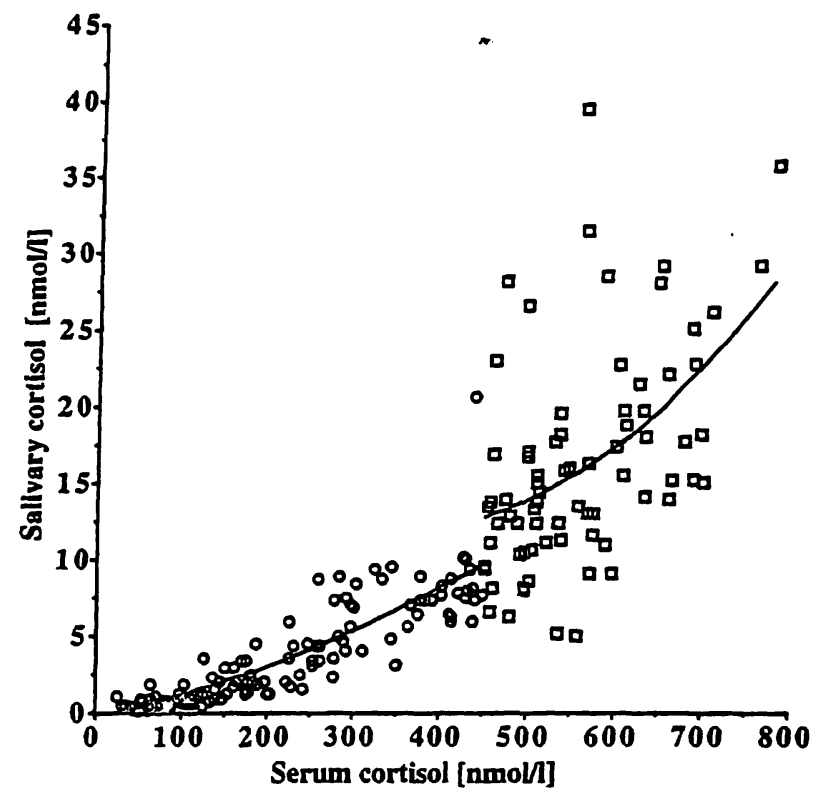

Fig. 1 Correlation between the concentrations of cortisol in saliva and serum.

Serum concentrations $<450 \mathrm{nmol} / \mathrm{l}(0) \mathrm{n}=244$.

Correlation with saliva concentrations $r=0.86(p<0.0001)$.

Serum concentrations $\geq 450 \mathrm{nmol} / \mathrm{l}(\square) \mathrm{n}=146$.

Correlation with saliva concentrations $r=0.44(p<0.0001)$.

$\mathrm{O} y=-0.33+0.01 \mathrm{x}+2.21 \times 10^{-5} \mathrm{x}^{2}$

$\square \mathrm{y}=22.33-0.06 \mathrm{x}+8.71 \times 10^{-5} \mathrm{x}^{2}$

ship was non-linear with $r=0.86$ for serum concentrations $<450 \mathrm{nmol} / \mathrm{l}$ and $\mathrm{r}=0.44$ for serum concentrations $\geq 450 \mathrm{nmol} / \mathrm{l}$. With serum concentrations above $450 \mathrm{nmol} / \mathrm{l}$ the ratio of saliva to serum concentration was increased from $2.1 \%$ to $3.0 \%$. Intra-individual variations in salivary cortisol concentrations and its relationship to serum cortisol are shown in figure 2.

The effect of blood contamination was tested by adding increasing amounts of blood to a saliva sample with a cortisol concentration of $7.4 \mathrm{nmol} / \mathrm{l}$. At a haemoglobin concentration of $2 \mathrm{~g} / 1$ a pellet of erythrocytes was visible after centrifugation but this small contamination did not increase the cortisol level. However, at a haemoglobin concentration of $5 \mathrm{~g} / \mathrm{l}$, the cortisol level was increased by $5 \%$, at $8 \mathrm{~g} / 1$ by $14 \%$ and at $12 \mathrm{~g} / 1$ by $30 \%$. In the reference material were included 26 samples with a haemoglobin concentration of $1-2 \mathrm{~g} / \mathrm{l}$ since this small contamination had no effect on the salivary cortisol concentration. Two samples were excluded from the reference material due to haemoglobin concentrations of $12 \mathrm{~g} / 1$ and $16 \mathrm{~g} / \mathrm{l}$, respectively.

\section{Discussion}

The mean salivary cortisol concentrations determined with the Coat-A-Count kit (DPC), $11.9 \mathrm{nmol} / 1$ at $8 \mathrm{am}$ and $1.8 \mathrm{nmol} / \mathrm{l}$ at $10 \mathrm{pm}$, may be compared to values obtained with other radioimmunoassays, i. e. a mean of
$15.5 \mathrm{nmol} / 1$ at 8 am and $3.9 \mathrm{nmol} / 1$ at $8 \mathrm{pm} \mathrm{(21)} \mathrm{and} \mathrm{a}$ median of approximately $11 \mathrm{nmol} / 1$ at $9-10.30$ am (22). Such minor differences in the results are to be expected considering the difference in method, population and sampling time. Alone the use of different radioimmunoassays may give concentration differences of $220 \%$ (23). Nevertheless, the reference range established in the current study, $3.5-27 \mathrm{nmol} / \mathrm{l}$ at $8 \mathrm{am}$ and $<6 \mathrm{nmol} / 1$ at $10 \mathrm{pm}$, does not differ much from the one earlier report of a reference range defined as the central $95 \%$, i. e. 5-28 $\mathrm{nmol} / \mathrm{l}$ (22). A reference range for evening cortisol concentrations was not given in this latter report. Other studies reporting on mean cortisol values, which abound in the literature, were either based on insufficiently defined populations as to age or sex distribution, or comprised relatively small numbers of subjects, at the most a few dozens (24). They were therefore apparently not intended for the establishment of reference ranges which demands well over 100 samples (25). Neither can a reference range be calculated from the occasionally given mean and standard deviation since the distribution of cortisol concentration is not Gaussian (own observation).

The higher cortisol concentrations in morning saliva in women under the age of 40 can be explained by their use of oral contraceptives $(26,27)$. Studies have revealed elevated salivary cortisol during the day in late pregnancy and after long-time use of oral contraceptives (9, 10). The cortisol in saliva being mainly free, implying that the elevation of the salivary cortisol concentration is not due to higher concentrations of transcortin. Many possible causes of the increased concentration of free cortisol have been suggested, one being an altered sensitivity of the hypothalamic-pituitary-adrenal axis by increased oestrogen levels (28). The slight decrease in morning cortisol concentrations with increasing age could be caused by a reduction in the transport of cortisol from blood to saliva due to physiological changes in old age (29).

When comparing salivary and serum cortisol concentrations, high correlations have been found with $r=0.71$ to $r=0.96(30)$. In this study a similar high correlation, $r=0.86$, is seen only with serum concentrations $<450$ $\mathrm{nmol} / \mathrm{l}$. The relation of salivary to serum cortisol concentration agrees well with theoretical considerations. Salivary cortisol has proved to be only about $70 \%$ of the free cortisol concentration in serum, probably due to the presence of $11 \beta$-hydroxysteroid-dehydrogenase in the salivary gland (16). At total serum cortisol concentrations of about $450 \mathrm{nmol} / \mathrm{l}$ with $3-5 \%$ in unbound form (7), the cortisol concentration in saliva would correspond to approximately $2.1-3.5 \%$ of total serum cortisol. In this study the concentration in saliva was on average $2.1 \%$ of serum concentrations $<450 \mathrm{nmol} / \mathrm{l}$ and $3.0 \%$ of serum concentrations $\underset{i}{\gtrless} 450 \mathrm{nmol} / \mathrm{l}$. 
As shown in figure 2, the relationship between individual values of cortisol in saliva and serum remained fairly constant in the 3 morning as well as the 3 evening samples. The 10 subjects apparently present individual patterns which may be due to different activities of the $11 \beta$-hydroxysteroid-dehydrogenase. Serum concentrations exceeding $450 \mathrm{nmol} / \mathrm{l}$ were in most cases accompanied by a marked increase in salivary cortisol.

Blood contamination of the saliva may cause spuriously high cortisol values. The risk of blood contamination is evident in patients suffering from gingivitis. In this study contamination occurred in $28(6 \%)$ of the samples.
However, only 2 of these were contaminated by blood in amounts that affected the result. To avoid this error, we propose that saliva samples with a visible erythrocyte pellet be analysed for haemoglobin and a new sampling made when the concentration is over $5 \mathrm{~g} / \mathrm{l}$.

An advantage of saliva over serum cortisol determination is the simple sampling procedure and thereby the avoidance of a stress-induced rise in cortisol concentration. Further, the sample can be taken by the patient at home and sent by mail to the laboratory for analysis. Transportation at room temperature is possible thanks to the stability of cortisol in saliva. The stability can be
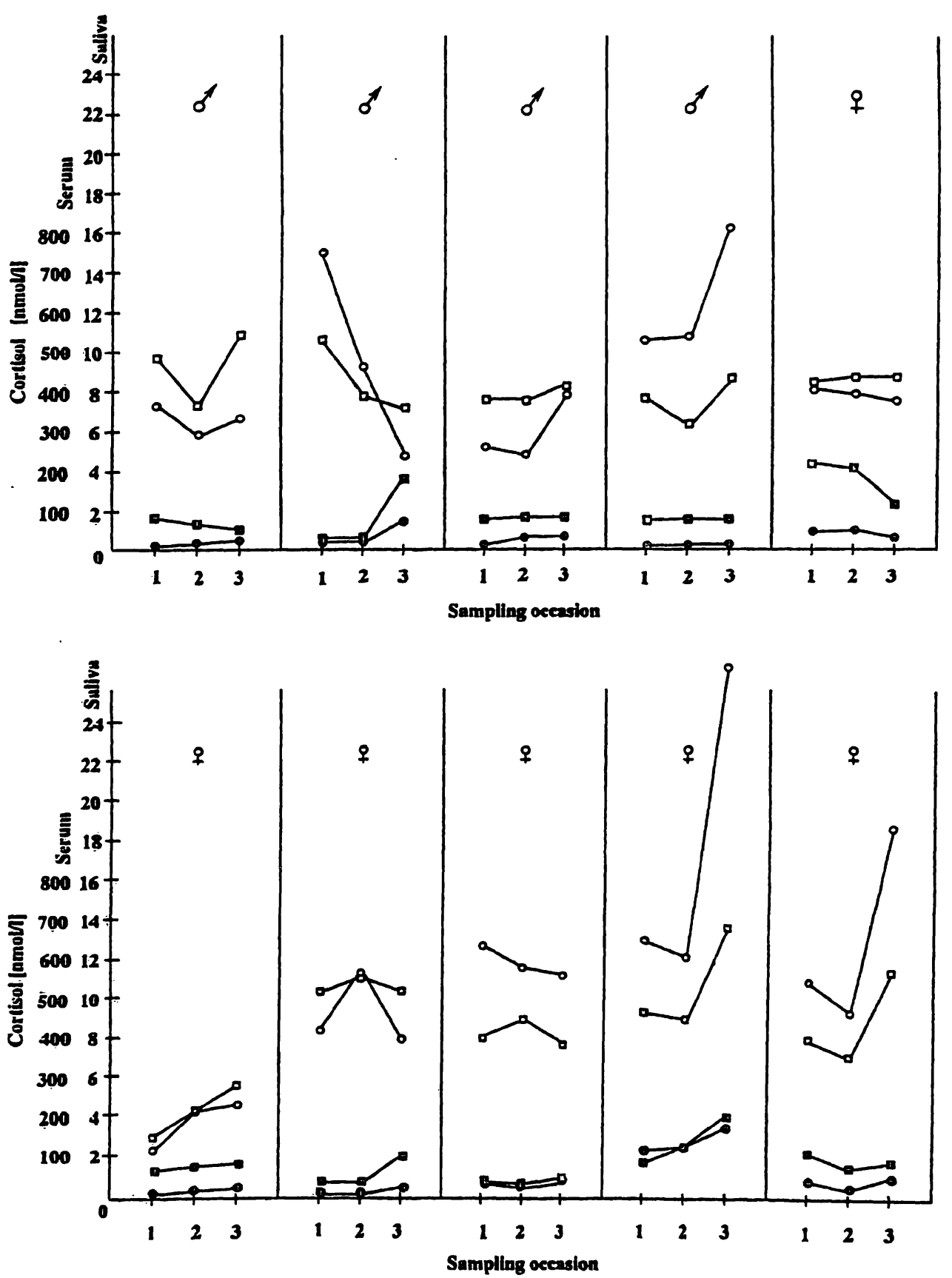

Fig. 2 Individual values of cortisol concentrations in saliva and serum in 10 subjects ( 4 men, 6 women). Morning and evening samples were collected within a 24 -hour period on three occasions at a week's interval.
Salivary cortisol concentration: Morning sample (0), evening sample (0).

Serum cortisol concentration: Morning sample ( $\square$ ), evening sample (口). 
further enhanced by the use of Salivette ${ }^{\circledR}$ tubes with citric acid treated swabs (31), but when measured with the DPC kit the cortisol concentration will then be higher in most samples. Sampling of saliva is therefore preferable under extreme conditions when transportation to the laboratory is delayed or when refrigeration facilities are not available (31). These advantages are of value in disaster research, where cortisol can be used as a marker for stress $(5,32)$. It is also useful in patients on whom venipuncture is difficult to perform and when repeated sampling is needed as in the assessment of hypothalamicpituitary-adrenocortical function $(7,33-35)$.

\section{References}

1. Carrol BJ. The dexamethasone suppression test for melancholia. Br J Psychiat 1982; 140:292-304.

2. Poland RE, Rubin RT. Saliva cortisol levels following dexamethasone administration in endogenously depressed patients. Life Sci 1982; 2:177-81.

3. Mason JW, Giller EL, Kosten TR. Urinary free cortisol levels in posttraumatic stress disorder patients. J Nerv Ment Dis 1986; 3:145-9.

4. Yehuda R, Southwick SM, Nussbaum SM. Low urinary cortisol excretion in patients with posttraumatic stress disorder. $\mathrm{J}$ Nerv Ment Dis 1990; 6:366-9.

5. Pitman RK, Orr SP. Twenty-four hour urinary cortisol and catecholamine excretion in combat related to posttraumatic stress disorder. Biol Psychiatr 1990; 27:245-7.

6. Dallman MF. Stress update: adaptation of the hypothalamic pituitary adrenal axis to chronic stress. Trends Endocrinol Metab 1993; 2:62-9.

7. Vining RF, McGinley RA, Maksyvitis JJ, Ho KY. Salivary cortisol: a better measure of adrenal cortical function than serum cortisol. Ann Clin Biochem 1983; 20:329-35.

8. Daughaday WH, Mariz UK. Corticosteroid-binding globulin: its properties and quantitation. Metabolism 1961; 10:936-50.

9. Landon J, Smith DC, Perry LA, Al-Ansari AAK. The assay of salivary cortisol. In: Read GF, editor. Immunoassays of steroids in saliva. Proceedings of the Ninth Tenovus Workshop, 1982 Nov; Cardiff: Alpha Omega Publishing Ltd. 1984:300-7.

10. Meulenberg PPM, Ross HA, Swinkels LMJW, Benraad TJ. The effect of oral contraceptives on plasma-free and salivary cortisol and cortisone. Clin Chim Acta 1987: 165:379-85.

11. Umeda T, Hiromatsu R, Iwaoka T, Shimada T, Miura F, Sato $T$. Use of saliva for monitoring unbound free cortisol levels in serum. Acta Clin Chem 1981; 110:245-53.

12. Hammond GL, Langley MS. Identification and measurement of sex hormone binding globuline (SHBG) and corticosteroid binding globuline (CBG) in human saliva. Acta Endocrinol (Copenhagen) 1986; 112:603-8.

13. Chu FW, Ekins RP. Detection of corticosteroid-binding-globulin in parotid fluids: evidence for the presence of both protein and non-protein-bound steroids in uncontaminated saliva. Acta Endocrinol 1988; 119:56-60.

14. Read GF, Riad-Fahmy D, Walker RF. Immunoassay of steroids in saliva. Cardiff: Alpha Omega Publishing Ltd. 1982:56.

15. Vining RF, McGinley RA, Symons RG. Hormones in saliva: mode for entry and consequent implications for clinical interpretations. Clin Chem 1983; 29:1752-6.

16. Read GF, Walker RF, Wilson DW, Griffiths K. Steroid analysis in saliva for the assessment of endocrine function. Ann NY Acad Sci 1990; 595:260-74.

17. Walker RF, Riad-Fahmy D, Read GF. Adrenal status assessed by direct radioimmunoassay of cortisol in whole saliva or parotid saliva. Clin Chem 1978; 24:1460-3.

18. Hiramatsu R. Direct assay of cortisol in human saliva by solid phase radioimmunoassay and its clinical applications. Clin Chim Acta 1981; 117:239-49.

19. Kirschbaum C, Wüst S, Strasburger CJ. 'Normal' cigarette smoking increases free cortisol in habitual smokers. Life Sci 1992; 6:435-42.
20. Snedecor GW, Cochran WG. Shortcut and non-parametric methods. In: Statistical methods. 6th ed. Ames: Iowa State University Press 1967: 120-71.

21. Laudat MH, Cerdas S, Fournier C, Guiban B, Guilhaume B, Luton JP. Salivary cortisol measurement: a practical approach to assess pituitary-adrenal function. J Clin Endocrinol Metab $1988 ; 66: 343-8$.

22. Al-Ansari AAK, Perry LA, Smith DS, Landon J. Salivary cortisol determination: adaptation of a commercial serum cortisol kit. Ann Clin Biochem 1982; 19:163-6.

23. Kirschbaum C, Strasburger CJ, Jammers W, Hellhammer DH. Cortisol and behavior: 1. Adaptation of a radioimmunoassay kit for reliable and inexpensive salivary cortisol determination. Pharmacol Biochem Behav 1989; 34:747-51.

24. Kirschbaum C, Hellhammer DH. Salivary cortisol in psychobiological research: an overview. Neuropsychobiology 1989; 22:150-69.

25. Lott JA, Mitchell LC, Moeschberger MI, Sutherland DE, Estimation of reference ranges: how many subjects are needed? Clin Chem 1992; 38:648-50.

26. Demey-Ponsart E, Foidart JM, Solton J. Serum CBG, free and total cortisol and circadian patterns of adrenal function in normal pregnancy. J Steroid Biochem 1982; 16:165.

27. Nolten WE, Lindheimer MD, Rueckert PA. Diurnal patterns and regulation of cortisol secretion in pregnancy. J Clin Endocrinol Metab 1980; 50:466-72.

28. Scott EM, McGarrigle HHG, Lachelin GL. The increase in plasma and saliva cortisol levels in pregnancy is not due to the increase in corticosteroid-binding globulin levels. J Clin Endocrinol Metab 1990; 71:639-44.

29. Reid JD, Intrieri RC, Susman EJ, Beard JL. The relationship of serum and salivary cortisol in a sample of healthy elderly. J Gerontol 1992; 3:176-9.

30. Kirschbaum C, Hellhammer DH. Salivary cortisol in psychoneuroendocrine research: recent developments and applications. Psychoneuroendocrinology 1994; 19:313-33.

31. Chem YM, Cintròn NM, Whiston PA. Long term storage of salivary cortisol samples at room temperature. Acta Endocrinol 1992; 119:56-60.

32. Yehuda R, Resnick H, Kahana B, Giller EL. Long-lasting hormonal alterations to extreme stress in humans: normative or maladaptive? Psychosom Med 1993; 2:287-97.

33. Hägg E, Olsson T, Granqvist $K$. Salivary cortisol during an overnight dexamethasone suppression test using a simple saliva collection device. Horm Metab Res 1990; 22:553-4.

34. Bolufer P, Gandia A, Rodrigues A, Antonio P. Salivary corticosteroids in the study of adrenal function. Clin Chim Acta 1989; 183:217-25.

35. Peters JR, Walker RF, Riad-Fahmy D, Hall R. Salivary cortisol assays for assessing pituitary-adrenal reserve. Clin Endocrinol $1982 ; 17: 583-92$.

Ann-Charlotte Holm M.D., Ph.D.

Faculty of Health Sciences

Department of Clinical Chemistry

S-581 85 Linköping

Sweden 